NBER WORKING PAPER SERIES

\title{
LENGTH OF SERVICE, TERMINATIONS AND THE NATURE OF THE EMPLOYMENT RELATIONSHIP
}

\author{
Katharine G. Abraham \\ James L. Medoff
}

Working Paper No. 1086

\author{
NATIONAL BUREAU OF ECONOMIC RESEARCH \\ 1050 Massachusetts Avenue \\ Cambridge MA 02138
}

March 1983

We are grateful to Henry Farber for consultations concerning the maximum likelihood estimates presented in the paper. Steven Bloom and Martin Van Denburgh gave invaluable assistance in carrying out the research to be discussed. We also owe thanks to Joyce Yearwood and Theresa Donovan for their careful preparation of the manuscript. This study has been supported by the National Science Foundation (Grant SES 82-08-539) and the National Bureau of Economic Research. The research reported here is part of the NBER's research program in Labor Studies. Any opinions expressed are those of the authors and not those of the National Bureau of Economic Research. 
Length of Service, Terminations and the Nature of the Employment Relationship

\section{ABSTRACT}

This paper presents new survey evidence that relative protection against job loss grows with length of service, independent of their net value to the firm. This protection makes good sense given that at most companies employees appear to earn less than their value marginal product in the early part of their tenure and more than their value marginal product in the latter part; without job protection policies for senior employees, the firm would have an incentive to terminate them when their "spot" earnings went above their "spot" value marginal product. In particular, we find that a very large percentage (over 95 percent) of hourly union members outside of agriculture and construction are covered by protective policies for senfor workers and, that a somewhat smaller, but still substantial, percentage (about 85 percent) of comparable nonunion hourlies also have some protection against job loss in their senior years. The potential reasons for these findings are briefly discussed.

Katherine G. Abraham Sloan School of Management Massachusetts Institute of Technology E52-453D

Cambridge, Massachusetts 02139

(617) 253-2661
James L. Medoff Department of Economics Harvard University Littauer Center 115 Cambridge, Massachusetts 02138 (617) 495-4209 
Over the course of the past several years, there has been a growing consensus among economists that wages grow more rapidly with company service than does productivity. Substantial empirical evidence supporting this proposition has been amassed and theorists have begun to develop coherent explanations for the deferral of compensation from early to late in the worklife. 1/ Clearly, employees should not be willing to accept wage schemes under which they are paid less than their current contribution early in the worklife and promised more than their current contribution later in the worklife unless they have some assurance of job security; 2 / under this sort of wage scheme, an employee who is prematurely terminated may lose compensation to which he or she is in some sense entitled. Given the existence of a substantial deferred-payment component in senior workers' wages, it is thus logical to ask the following questions: What guarantee do senior workers have that they will not be involuntarily separated from their jobs? How does the strength of this guarantee vary across settings?

The responses to a mail questionnaire which we recently sent to a large sample of U.S. firms have provided useful data for answering the above questions. Based on our survey results, we reach two central conclusions. First, for a large majority of both union and nonunion employees, protection against job loss grows with seniority. Reasonable estimates are that over 80 percent of nonunion employees and almost 100 percent of union employees are employed in settings where senior employees are favored substantially in reduction in force decisions, so that junior employees are laid off instead of senior employees considered to be worth less on net to the firm. Second, the relative risk of senior employees losing their jobs is substantially 
smaller in union settings than in comparable nonunion settings, even when written provisions making seniority the most important factor in layoff decisions are found at both.

Section I of the paper describes the collection of the survey data on which our conclusions are based. The survey results appear in the next two sections of the paper, with information on written layoff provisions presented in Section II and our central results on actual layoff practice presented in Section III. The paper's concluding section deals with the interpretation and implications of our findings.

I. Collection of the Data

We sent our survey to 1,025 randomly selected nonagricultural, nonconstruction firms from the 1981 edition of Standard and Poor's Register and 250 randomly selected manufacturing firms from a 1980 News Front listing of approximately 3,000 publicly held manufacturing corporations. Firms based outside the U.S. were excluded from both samples. Standard and Poor's generally lists companies with 50 plus employees and $\$ 1,000,000$ plus in sales in their Register. What fraction of total U.S. nonagricultural, nonconstruction employment do these companies represent? Tabulations based on the May 1979 Current Population Survey show that 56 percent of those whose primary employment was in the nonagricultural, nonconstruction private sector said they worked for companies with 100 plus employees and 70 percent said they worked for companies with 25 plus employees. Data from the ES-202 program indicate that unemployment insurance reporting units with 50 or more employees account for 64 percent of total covered private sector employment outside agriculture and construction; since firms may contain more than one unemployment insurance reporting unit, firms with 50 or more employees 
should account for some larger fraction of covered employment in the relevant sectors. A conservative guess would be that the standard and Poor's listing contains firms accounting for perhaps two-thirds of total U.S. nonagricultural, nonconstruction employment. We chose to oversample manufacturing by adding companies from the News Front list because of the very large fraction of the economy-wide variation in employment which occurs in this sector.

Whenever possible, we mailed our survey to that individual at each firm who appeared to be in charge of personnel matters (e.g., the Executive Vice-President for Personnel, the Personnel Director or the Industrial Relations Vice-President). In cases where no such individual's name could be obtained, the letter was sent to the Chief Executive officer of the corporation. If no response was recelved from a firm within six weeks after our first request was mailed, a second request was sent to the original contact. Altogether, we received 429 responses from firms in the Standard and Poor's sample (a response rate of 42 percent) and 113 responses from firms in the News Front sample (a response rate of 45 percent). Because of various data problems, there were in both cases somewhat fewer usable responses.

A question at the start of the survey form asked how many exempt employees (most likely managers and/or professionals), nonexempt salaried employees and hourly employees were affected by the respondent's personnel decisions; all subsequent answers refer to the largest of these subordinate groups. One of the later questionnaire items inquired whether a majority of those in the relevant group were covered by a collective bargaining agreement. In the analysis which follows, we look separately at three response categories: union hourly employees; nonunion hourly employees; and nonunion salaried employees (nonexempt and exempt combined). 3 / 
Much previous work on the role played by seniority in layoff decisions has focused on collectlve bargaining agreement provisions. We asked whether either a collective bargaining agreement or a written policy dealing explicitly with the role of seniority in permanent layoff decisions covered the group of employees referred to by each respondent. Where we were told that such an agreement or policy did exist, we asked whether the relevant language stated that seniority should be the single most important factor in determining who would be laid off in the event of a permanent workforce reduction.

Our primary objective was to learn more about actual practice concerning the role of seniority in permanent layoff decisions. Those respondents who had witnessed a reduction in force which affected the relevant work group were asked the following question:

In the event of a workforce reduction, are senior employees permanently laid off in place of junior employees?

I Yes, if it is believed that the junior employee will be worth more on net to the company than the senior employee.

IT Yes, if it is believed that the junior employee will be worth significantly more on net to the company than the senior employee.

IT No, never.

This question produces the most important information in our data set. The responses indicate the strength of the favoritism afforded senior employees when permanent layoffs occur.

In addition to the above information pertaining to permanent layoff policies and practices, we also asked our survey respondents to tell us the following: number of people employed by the firm (used in In units as a firm size measure); information on products produced by the firm (used to construct industry dummies); and the respondent's address (used to create region dummies). 


\section{Written Layoff Provisions Covering Various Groups}

As stated above, our questionnaire asked about written layoff provisions covering both nonunion and union employee groups. The Bureau of Labor statistics has published data on the prevalence and characteristics of layoff provisions contained in major collective bargaining agreements; however, to the best of our knowledge, there exist no similar data on layoff provisions contained in written policies covering nonunion employees.

Table 1 summarizes the relevant raw responses from our Standard and Poor's firms. Almost a quarter of nonunion hourly groups (24 percent) are covered by written layoff provisions which specify the role of seniority in permanent layoff decisions. Interestingly, where such written provisions covering nonunion hourly groups exist, a relatively large fraction (68 percent) state that seniority should be the most important factor in deciding which employees to let go. Taken together, the above figures imply that approximately 16 percent of nonunion hourly employee groups are covered by written provisions which specify that seniority should be the most important factor in permanent layoff decisions. Separate tabulations indicate that, among nonunion hourly employee groups, those at larger firms are more 1ikely to be covered by this sort of provision, a result which holds up even when industry and region are controlled for. We return to this finding below. The nonunion salaried responses indicate that only a tiny fraction of those employee groups (under 3 percent) are covered by written last-in-first-out layoff provisions.

How does unionization affect the probability that the rules governing seniority's role in cutbacks will be spelled out in writing? Fully 92 percent of the responses for hourly union employees (versus 24 percent for hourly nonunion employees) indicated the presence of written 
Table 1: Data from Standard and Poor's Sample on Contract and written

Policy Provisions Governing Permanent Layoffs

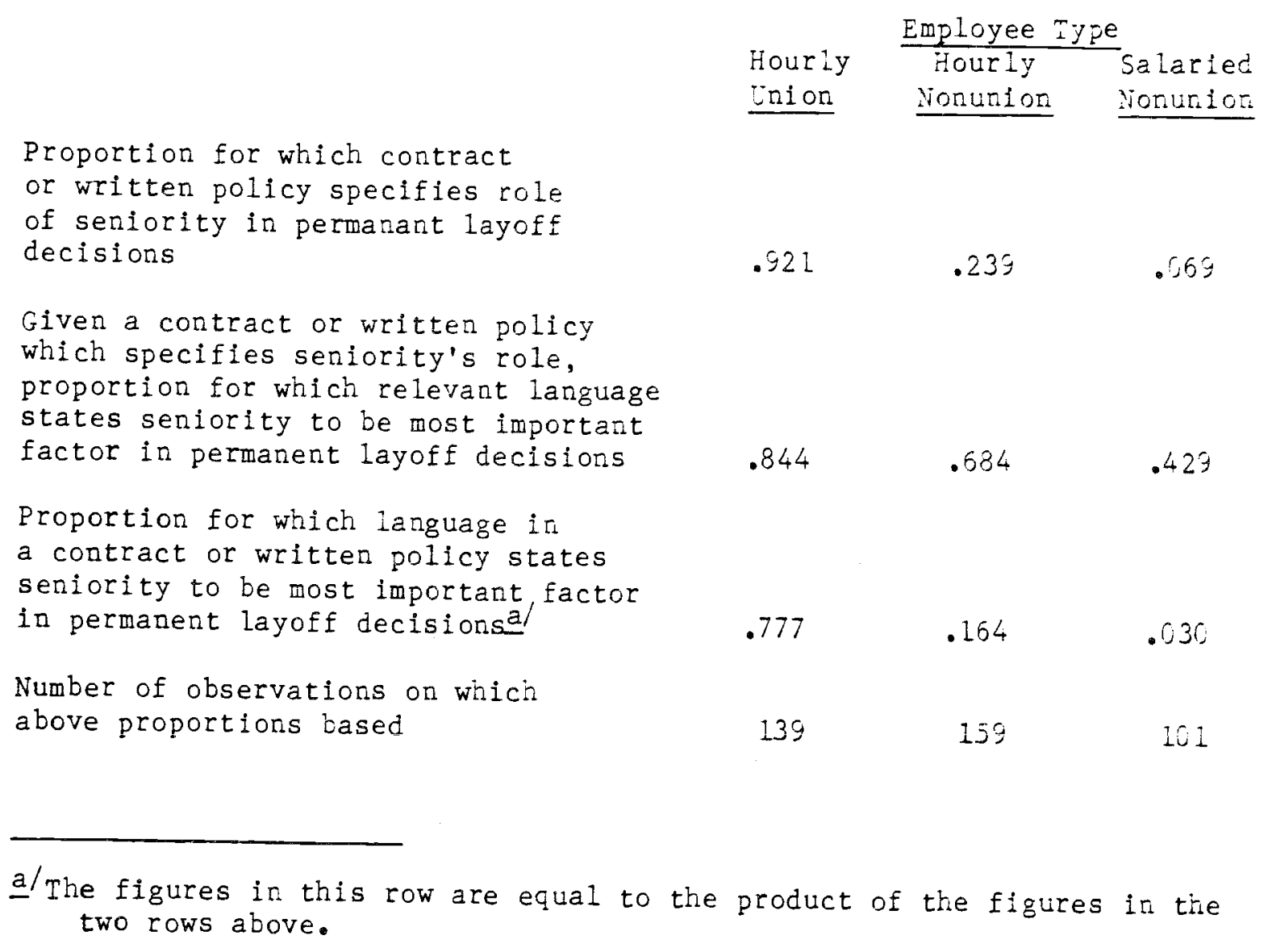


provisions dealing with the role of seniority in permanent layoff

decisions. of such provisions covering hourly union employees, 84 percent (versus 68 percent for hourly nonunion employees) stipulated that seniority should be the most important factor in layoff decisions. Overall, the above proportions imply that 78 percent of union hourly groups (versus 16 percent of nonunion hourly groups) are covered by written provisions which make seniority the most important factor in permanent layoff decisions.

The raw figures presented in Table 1 could potentially be misleading insofar as the responses we received from firms on our standard and Poor's 1ist were not randomly distributed with respect to firm size and industry (as reported in the Register listings for the firms we surveyed). Large firms were more likely to return our questionnaire than small firms. Firms in the mining, manufacturing, transportation, communications, utilities, or trade sectors were more likely to provide answers pertaining to hourly employees than were firms in the service, finance, insurance or real estate sectors; the opposite was true for answers pertaining to salaried employees. In addition, it would arguably be preferable to estimate the proportion of employment to which a given statement applied rather than the proportion of employee groups to which the same statement applied. These considerations lead us to develop two sets of weighted figures. The first set of weights corrected for response rate variation across nine firm size/Industry cells; the second set yielded estimates of employment proportions rather than employee group proportions. These weightings did not change any of our qualitative conclusions.

A further concern is that the figures presented in Table 1 might be misleading if the respondent firms differed systematically in unobservable ways from the nonrespondent firms. Obviously, we have no direct information on the answers that nonrespondents would have given to our survey 
questions. However, we do have answers both from firms that responded to our original mailing and from firms that responded only after we sent them a followup mailing. Comparison of early versus late responders provides a seemingly reasonable test of whether our estimated proportions should be considered suspect because of likely nonresponse bias. We divided the sample used in Table 1 into early responders and late responders, then recalculated the raw proportions presented there separately for the two groups. The only noteworthy difference is that early nonunion hourly respondents were significantly more likely than late nonunion hourly respondents to report the existence of a written policy governing the use of seniority in permanent layoff decisions (.283 versus .135). This gap does not appear to be attributable to differences in the firm size, industry and/or region characteristics of the two groups. Thus, the Table 1 figures for the nonunion hourly population must be treated with some caution. Partial confirmation that the figures presented in Table 1 are reasonable can be garnered from Bureau of Labor Statistics (BLS) data on major collective bargaining agreement provisions. The most recent relevant BLS data are for 1970-1971. They indicate that 95 percent of major collective bargaining agreements outside of construction contain some type of layoff provision. Examination of a sample of those contracts containing layoff provisions showed seniority to be the "sole" or "primary" factor in determining layoff rights for 74 percent of the contracts in the sample, exclusive of those contracts in which the issue was "subject to local negotiations." 1 / Combining the relevant fractions, the BLS data imply that just over 70 percent of union hourly employee groups are covered by layoff provisions which specify that seniority should be the most important factor in permanent layoff decisions; the comparable figure derived from our Standard and Poor's responses was 78 percent. 
III. Practice Concerning the Role of Seniority in Actual Layoff Decisions

U1timately we would like to know not only what written policies or collective bargaining agreements say about the role of seniority in permanent layoff decisions but also how much weight seniority actually receives when a reduction in force occurs. In this section, we first discuss the strengths and weaknesses of the survey data we have collected for exploring actual layoff practice. Our next step is to look at the overall pattern of responses to our question concerning how permanent layoff decisions are made. We then proceed to a more careful examination of the various factors which we expect to influence the weight given to seniority in reduction-in-force situations, giving particular consideration to union versus nonunion differences.

$\underline{\text { Pros and Cons of Using Survey Data to Explore Layoff Practice }}$

There are several reasons for our belief that the survey data on layoff practice we have collected can provide a better overall picture of the role played by seniority in firms' permanent layoff decisions than any feasible analysis of actual layoff rates.

Suppose that we could obtain detailed personnel records for a large number of firms that had carried out reductions in force. These records could be used to calculate firm-specific permanent layoff rates for employees with varying amounts of seniority. Unfortunately, a lower layoff rate among senior employees at any particular firm could result either from those employees having greater expected net worth or from their receiving favored treatment. Thus, this layoff rate information would have to be supplemented with information on individuals' expected net worth to their firms before one could be certain of its interpretation. Our questionnaire 
asks whether senior employees are favored in permanent layoff decisions rather than whether layoff rates are lower among senior employees. The responses obtained thus should shed light on an issue that layoff rate data alone could never help us with.

In actual fact, firm-specific layoff rates for workers with different amounts of seniority would be exceedingly difficult to obtain. Longitudinal micro data sets like the National Longitudinal Survey (NLS) and the Panel Study of Income Dynamics (PSID) are possible sources of information on permanent layoff rates. There are at least two serious problems with using these data for the purpose at hand, in addition to that discussed above. First, the unit of observation is the individual, not the firm. To see how this might cause problems, suppose that union sector layoffs typically occurred at sites with mostly long-service employees but that nonunion sector layoffs typically occurred at sites with mostly recently-hired employees. In this situation, even if senior union employees at any given site are relatively less likely to be laid off than would be true without a union, the aggregate data might show less decline in the layoff rate with length of service in the union sector than in the nonunion sector. This sort of problem can only be avoided through the use of firm level, rather than individual level, data. A second problem with both the NLS and the PSID is that the sample sizes are relatively small. For example, the PSID offers usable observations on permanent layoff experience over the 1974-1975 period for only 70 private sector nonagricultural, nonconstruction union blue collar workers with 20-plus years of company service and for only 43 comparable nonunion workers. These may sound like reasonably large numbers; however, even during the 1974-1975 recession the annual permanent layoff rate for individuals with 20 plus years of company 
service was probably no more than 5 percent, so that much larger numbers would be needed to reliably detect even large proportional differences between the union and the nonunion rates.

The survey data on layoff practice analyzed in this section of the paper have the advantages of pertaining directly to the question of whether senior employees are favored in permanent layoff decisions and of providing a relatively large number of firm-level observations. Perhaps the most serious shortcoming of the data is that each observation represents only one person's assessment of how layoff decisions at his or her firm are made. Ideally, one would like to collect information on of the layoff decision process at each firm from people at all levels of the corporate hierarchy, including those at lower levels as well as those at the top level. Another potential weakness of the data is that our respondents might not be wholly candid concerning seniority's role in permanent layoff decisions. While this possibility cannot be ruled out, we see no good reason for our respondents to mislead us, particularly since they were assured that their responses would be kept strictly confidential. On balance, we would argue that our data represent the best available source of information for exploring the role played by length of service in reductions in force.

The Pattern of Actual Layoff Practice

Table 2 summarizes the raw responses concerning actual layoff practice received from our Standard and Poor's firms. A substantial majority of the answers pertaining to nonunion hourly groups indicate that senior employees enjoy considerable protection against being permanently laid off, meaning either that a senior employee would never be let go ahead of a junior employee ( 42 percent of all responses) or that this would occur 
only if the junior employee was considered to be worth significantly more to the firm on net ( 44 percent of a11 responses). Even among the responses pertaining to nonunion salaried groups, 24 percent indicate that a senior employee would never be let go ahead of a junior employee and 57 percent indicate that this would occur only if the junior employee was considered to be worth significantly more to the firm on net.

How does the layoff protection afforded senior union employees compare to that afforded senior nonunion employees? Comparing the relevant figures for union hourly and for nonunion hourly employee groups, 97 percent of the union respondents versus 86 percent of the nonunion respondents reported substantial protection for senior employees and 84 percent of the union respondents versus 42 percent of the nonunion respondents reported that a senior employee would never be let go in place of a junior employee. Thus, layoff protection for senior union employees seems to be both more prevalent and stronger than that for senior nonunion employees in broadly similar jobs.

We also calculated two sets of weighted proportions like the raw proportions just discussed. The first set of weights corrected for response rate variation across nine firm size/industry cells and the second set yielded estimates of employment proportions rather than employee group proportions. None of the weighted proportions differs appreciably from the comparable raw proportions.

To determine whether we ought to be concerned about possible nonresponse bias in the figures presented in Table 2, we again divided the observations into those received from early responders and those recelved from late responders, then prepared separate tabulations for the two groups. There were no significant differences between the two sets of numbers. 
Table 2: Data from Standard and Poor's Sample on Actual Practice Concerning the Role of Seniority in Permanent Layoff Decisions-

\begin{tabular}{lll} 
Hourly & \multicolumn{2}{c}{ Employee Type } \\
Union & Nonunion & Salaried \\
&
\end{tabular}

Proportion reporting that senior employee never let go ahead of junior employee

.423 .238

Proportion reporting that senior employee let go if junior employee believed to be worth significantly more on net

Proportion reporting that senior employee let go if junior employee believed to be worth more on net .141 .190

Number of observations on which above proportions based

a/ only respondents who had witnessed permanent layoffs were asked what practice was followed in deciding which employees to let go. 
Modelling the Analysis of Factors Affecting Actual Layoff Practice

What underlies the union/nonunion differences in layoff practice just noted? Given similarly-worded written policy statements governing the role of seniority during reductions in force, are the actual layoff practices followed in union and nonunion settings also similar? In econometric terms, answering these questions requires that we explain the variation in a trichotomous dependent variable which captures senior employees' vulnerability to being involuntarily terminated ahead of junior employees during a reduction in force. This can be modelled using an ordered probit. Assume that there exists some unobserved continuous variable, $y$, which measures senior employees' relative vulnerability to layoff. We do not observe y directly but do have some information about $y$. Specifically, it can be assumed that if the $y$ value for a particular group is below some threshold $c_{1}$, our survey respondents will say that a senior employee would never be let go before a junior employee; that if $y$ is between $c_{1}$ and some higher threshold level $c_{2}$, respondents will say that a senior employee would be let go before a junior employee only if the junior employee was worth significantly more on net to the company; and that if $\mathrm{y}$ is above $c_{2}$, respondents will say that a senior employee would be let go before a junior employee if the junior employee was worth more on net to the company. Let the latent variable $y$ be a function of various $X$ 's including union status and the terms of written layoff provisions:
(1) $\quad \mathrm{y}=\tilde{\mathrm{x} \beta}+\varepsilon$

where $y$ represents the unobserved continuous measure of senior employees' vulnerability to permanent layoff, the $X ' s$ are independent variables, the $\beta$ 's are parameters, $\varepsilon$ is an error term, and 1 indexes observations. If the 
Es are normally distributed, the probability of a respondent indicating that a senior employee would never be involuntarily terminated before a junior employee is equal to:

(2) $\frac{1}{\sqrt{2 \pi}}{ }^{c_{1}-\tilde{X} \beta} \exp \left(-z^{2} / 2\right) d z$,

the probability of a respondent indicating that only a senior employee who was worth significantly less on net than a junior employee would be let go first is equal to:

(3) $\frac{1}{\sqrt{2 \pi}}{ }_{c_{1}-\tilde{X} \beta}^{c_{2}-\tilde{X \beta}} \exp \left(-z^{2} / 2\right) d z$,

and the probability of a respondent indicating that a senior employee would be permanently laid off before a junior employee who was worth more on net is equal to:

(4) $\frac{1}{\sqrt{2 \pi}} \int_{\sim \sim}^{\infty} \exp \left(-z^{2} / 2\right) \mathrm{d} z$,

Standard maximum likelihood methods can be used to estimate $c_{1}, c_{2}$ and the $\beta$ 's. Given the way the model has been set up, a positive coefficient implies greater senior employee vulnerability to being involuntarily terminated.

\section{Factors Affecting Senior Employees' Relative Vulnerability to}

Permanent Layoff

The models presented in Table $3 \mathrm{~A}$ were estimated using the ordered probit technique just described. We included responses from firms in our News Front sample in estimating these equations. Since the various 
potentially relevant factors are likely to have a different impact on permanent layoff decisions affecting salaried employees, we included only union hourly and nonunion hourly observations in the sample used to fit these models.

Column (1) presents the coefficient estimates obtained for a mode1 which included a union dummy plus firm size, industry and region variables. The union hourly dummy assumes a large, statistically significant positive coefficient. Thus, controlling for size of firm, industry and region does not alter the conclusion which emerged from the simple cross-tabulations in Table 2, that senior union hourly employees are relatively less vulnerable to permanent layoff than senior nonunion hourly employees. The coefficient estimates from model (1) can be used to predict the probability that union and nonunion respondents with otherwise average characteristics for nonagricultura1, nonconstruction blue collar workers (as derived from the May 1979 CPS) would give each of the three possible answers to the question we asked about the role of seniority in actual layoff decisions; these probabilities are reported in Table $3 B$. Union respondents are almost twice as likely as similar nonunion respondents to say that a senior employee would never be permanently laid off in place of a junior employee $(.773$ versus .410); union respondents are 6.5 times less likely than similar nonunion respondents to say that a senior employee would be permanently laid off if it was believed that a junior employee would be worth more on net $(.025$ versus .162).

While the result just documented is interesting in itself, it also raises some further questions. In particular, we wondered whether union and nonunion employee groups covered by similarly-worded written layoff policies would in fact be treated similarly when workforce reductions occurred. Column (2) reports on the results of estimating an ordered probit equation 
Table 3A: Factors Affecting Actual Practice Concerning the Role of Seniority in Permanent Layoff Decisionsat

Coefficient estimates from ordered probit equations in which three dependent variable categories reflect senior employees' vulnerability to permanent layoff

Mean

[ Standard ( $\quad(\mathrm{N}=203)$ Deviation] (1) (2)

Union hourly group $($ yes $=1)$

$\begin{array}{lll}.512 & -.977 & -.588 \\ {[.501]} & (.190) & (.240)\end{array}$

Written layoff provision .527 specifying seniority $[.501]$ $-.981$ key factor in permanent layoff decisions (yes $=1$ )

other written layoff provision $($ yes $=1)$

$[.138$

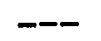

(.287)

Ln (number persons employed)

6.239

[1.828]

$$
-.008
$$

$(.045)$

Trade, transportation, communications and utilities (yes $=1$ )

$[.113$

$-.074$

$(.513)$

$-.338$

Services, finance, insurance and real estate $($ yes $=1$ )

Northeast $($ yes $=1$ )

$\begin{array}{lll}.350 & -.412 & -.330 \\ {[.478]} & (.221) & (.251)\end{array}$

South $($ yes $=1)$

$$
.167
$$

.182

.157

[. .374]

(.255)

$(.254)$

West $($ yes $=1$ )

.128

$-.082$

$-.101$

[.335]

$(.322)$

(.337)

$c_{1}$
$c_{2}$
$x^{2}$
$d . f$.

$\begin{array}{ccc}- & -.200 & -.197 \\ - & (.357) & (.391) \\ - & 1.013 & 1.126 \\ -(.335) & (.385) \\ - & 39.0 & 65.3 \\ - & 7 & 9\end{array}$

at These estimates are based on data from both the Standard and Poor's and the Newsfront samples. Only respondents who had witnessed permanent layoffs were asked what practice was followed in deciding which employees to let go. 


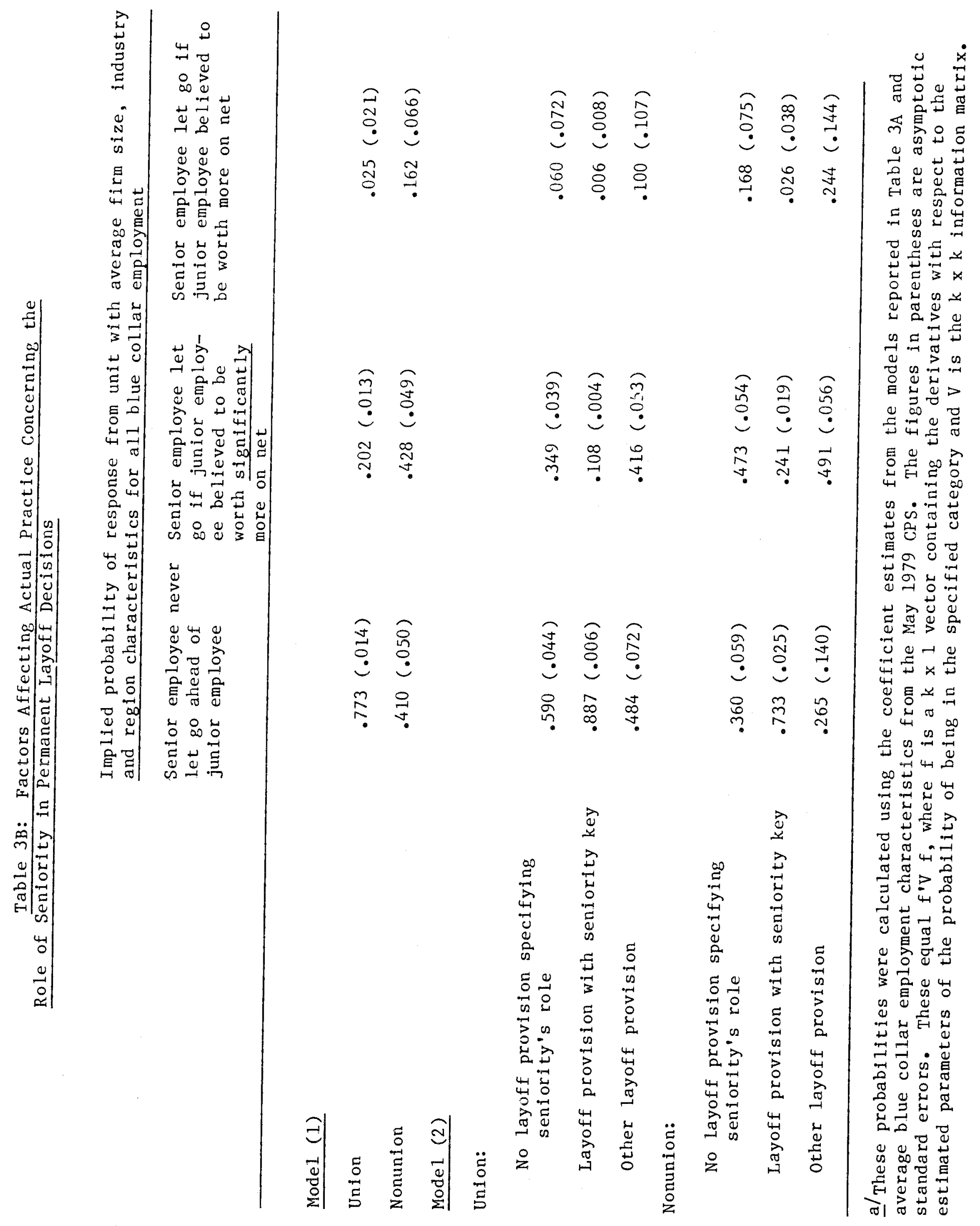


which includes a union hourly dummy plus a dummy variable which equals one If there is a written layoff provision specifying that seniority should be the most important factor in permanent layoff decisions and a second dummy variable which equals one if there is some other written layoff provision, in addition to firm size, industry, and region controls. Two things about the parameter estimates obtained are of particular interest.

The first noteworthy fact is that, not surprisingly, written provisions which specify that seniority should be the most important factor in layoff decisions are associated with a substantial reduction in senior employees' relative vulnerability to losing their jobs. As can be seen by looking at Table 3B, coverage by a last-in-first-out layoff provision increases the probability of a "senior employee never let go before a junior employee" response by .297 for a union group with otherwise average characteristics (from .590 to .887) and by .373 for a comparable norunion group (from .360 to .733 ). The corresponding reductions in the probability of a "senior employee let go if junior employee believed to be worth more on net" response are .054 for a union group with sample average characteristics (from .060 to .006 ) and .142 for a nonunion group with sample average characteristics (from .168 to .026). 5/ Written layoff provisions which do not specify that seniority should be the key factor in layoff decisions have no statistically significant estimated effect on senior employees' vulnerability to losing their jobs.

The second noteworthy fact is that unionism per se still seems to matter even after the above-described written layoff provision variables are introduced. The union hourly dummy coefficient in the column (2) equation is strongly significant. On average, unionization is associated with a .189 increase in the probability of a "senior employee never let go before a junior employee" response (from .543 to .732 ) and with a .066 decrease in 
the probability of a "senior employee let go if junior or employee believed to be worth more on net" response (from .103 to .037). These effects are roughly 50 percent as large as the corresponding effects derived from the model which included no layoff provision controls, meaning that differences in the existence and nature of written layoff provisions covering union versus nonunion groups can account for perhaps half of the reduction in senior employees' vulnerability to layoff that is associated with union status.

The Table 3 models do not directly address the question of which senior nonunion hourly employees enjoy the greatest protection against being permanently laid off. We estimated a second set of models like those in Table 3 using only nonunion hourly observation. Since nonunion hourly employee groups at larger firms are significantly more likely to be covered by written provisions specifying a key role for seniority in permanent layoff decisions, we expected that the 1 in of employment variable in the model patterned after that in column (1) would assume a significant negative coefficient. This coefficient was in fact close to zero and statistically insignificant. One way to state these results is that large and small employers of nonunion hourly employees differ more in form than in substance with regard to layoff decisions affecting long-service workers.

Are the results presented in Table 3 apt to be contaminated by nonresponse bias? The appropriate $\chi^{2}$ tests show that neither adding a dummy variable which captures whether an observation represents a late responder nor adding a full set of interaction terms to the ordered probit equations contributes to the models' explanatory power.

We were also concerned about the possible existence of a somewhat different type of bias that has not been mentioned until this point. One might argue that what we should be interested in knowing is the distribution 
across all employers of practice with regard to the role played by seniority in the event a permanent layoff occurs; what we actually observe is the distribution of relevant practice across the set of employers such that respondents there have witnessed reductions in force. These two distributions may differ. One might expect that firms which avoid layoffs as a matter of policy might also place greater emphasis on seniority in the event that a layoff does occur. There is no satisfactory method of dealing with this problem. However, we did experiment with estimating a censored ordered probit model. Censoring takes place because we only observe layoff practice at those firms where our respondents have witnessed reductions in force; we specified a probit equation containing the $1 \mathrm{n}$ of firm size, industry dummies and region dummies to describe this censoring process. We then reestimated each of our ordered probit equations simultaneously with this censoring equation using maximum likelihood methods, allowing for some correlation rho between the relevant errors. Unfortunately, we were unable to achieve usable estimates. 6/ At this point, the best we can do is note that the censoring of our data is a potential concern.

IV. Concluding Thoughts

The results just reported indicate that over 80 percent of private sector nonagricultural, nonconstruction employment is located in settings where senior workers enjoy substantial protection against losing their jobs. One would expect at least a credible promise of this sort of protection to accompany wage policies which pay workers less than their value marginal product early in their tenure and more than their value marginal product late in their tenure. Nonetheless, it might be asked what actually motivates firms to adhere to a practice of favoring senior 
employees when cutbacks affecting their nonunion workforce occur, given that there would appear to be a short-run incentive to terminate senior employees instead of junior employees expected to be worth more on net to the firm. Someone unacquainted with U.S. law might suppose that senior nonunion workers were guaranteed some legal protection against losing their jobs. In fact, senior nonunion workers have virtually no legal recourse if they are laid off before their juniors. Ignoring situations in which a termination has been predicated on a consideration expressly made unlawful by statute (e.g., sex, race, religion, national origin, age, union organizational activity, or protected concerted activity), nonunion employment relationships are generally "terminable at will," regardless of an employee's length of service. Even written company manuals stating that layoffs will occur in inverse order of years of service have not generally been viewed by the courts as enforceable contracts, because employers have the right to alter this "policy" at any time. l Nevertheless, it appears that practices favoring senior workers do go hand in hand with stated policies to that effect; our survey responses indicate that nonunion firms with inverse-seniority layoff policies are second only to union firms with such provisions in their collective bargaining contracts when it comes to actually protecting senior workers' jobs.

Other possible motivations for nonunion firms to protect the jobs of senior workers where current pay is above current contribution include: avoiding unionization; maintaining the morale of the current workforce so that short-term efficiency is not impaired; and preserving the firm's reputation as a fair employer so that prospective new hires are not deterred from joining the firm's workforce. Information concerning the relative importance of these three potential motivators would greatly enhance our understanding of the issue at hand. 
While a significant number of senior hourly nonunion workers are protected against some forms of job loss, senior hourly union workers are both more often protected and better protected. As mentioned above, we estimate that almost 100 percent of private sector hourly union workers outside of agriculture and construction receive job loss protection, compared to about 85 percent of such nonunion workers; further, we estimate that over 80 percent of these hourly union workers were covered by plans which would "never" result in the involuntary termination of a senior employee in place of a junior employee, whereas only about 40 percent of such hourly nonunion workers were so securely protected. Why do union members recelve better protection than comparable nonunion workers? One reason for expecting senior workers to be more favored in layoff decisions in union than in nonunion settings is that the collective bargaining process very 11 kely leads to older workers' preferences receiving greater weight than they otherwise would. - Unionism also adds two enforcement mechanisms: the law and the union itself. As discussed above, nonunion workers are generally not protected by law from losing their jobs in place of more junior employees; union members' contracts are enforceable in court and so have added weight. In addition, the union itself can monitor employer actions to ensure employer compliance with seniority rules; in a nonunion setting, most workers will probably not have much power to make sure the employer is keeping his word. And, in the most desperate situations, the union can organize work interruptions, giving it a powerful bargaining tool in the establishment, preservation, and carrying out of seniority provisions.

Our result that senior unionized workers enjoy relatively greater protection against job loss than comparable senior nonunion workers may help with the resolution of a puzzle that has disturbed diverse analysts. Numberous studies of the impact of trade unionism have concluded that length 
of service raises union wages less than nonunion wages, which suggests that senior workers benefit less from unionism than do junior workers. This result is puzzling because, as just stated, it is generally supposed that senior workers' preferences carry greater weight in union settings. Recent research suggests that the solution to this paradox may be found in a demonstration that, whereas wages rise less rapidly with seniority under unionism, the expected value of total compensation rises more rapidly. $\underline{9}$ One of the most important benefits increasing the slope of the union-service/ expected-economic-rewards profile is the greater job protection provided under unionism.

Thus far in this paper we have presented evidence that senior unionized workers enjoy greater protection against permanent layoff vis-a-vis junior unionized workers than do senior nonunion workers vis-a-vis junior nonunion workers. Is it also true that senior unionized workers are less vulnerable to losing their jobs than senior nonunion workers? To put the issue somewhat differently, we have shown that unionism reduces senior workers' relative vulnerability to permanent layoff; is it also true that unionism reduces sentor workers' absolute vulnerability? This might not be the case if the presence of a union increased the overall permanent layoff rate sufficiently to outweigh the fact that senior union workers are lower on the list of those to be let go. Back-of-the-envelope calculations based on our survey data suggest that senior union workers have a much lower probability of being permanently laid off than do senior nonunion workers. $10 /$ Francine Blau and Lawrence Kahn have recently reported on the 1971-1972 permanent layoff experience of those included in the NLS male panels; their results are supportive of the belief that, among older (presumably more senior) men, coverage by a collective bargaining agreement is associated with a lower permanent layoff rate. $11 /$ other evidence on 
union policies during downturns is consistent with these findings. While during mild recessions, unions favor the use of temporary layoffs to maintain high wage rates, as downturns begin to threaten the jobs of senior employees, unions become more willing to discuss wage cuts, reopening of contracts, and changes in work rules and policies. This change in union behavior can be seen by studying the 1974-1975 and current recessions. 12 / To summarize, we have found that even though senior nonunion workers are often protected against job loss in place of more junior workers, unionism raises the incidence and strength of such protection. While both implicit and explicit contracts may exist, they appear to have significantly different consequences for senior workers. Job rights appear to grow with seniority to a much greater extent under collective bargaining. 
1/ For a summary of empirical evidence pertaining to the deferral of compensation from early to late in the workife, set Medoff ard ktrahau [1981]. Theoretical work related to the question of why such deferred compensation schemes might be adopted includes Becker ard stigler [1974], Salop and Salop [1976], Viscusi [1978], Lazear [1979], Harris and Holmstrom [1981], and Iacnnides and Pissarides [1982].

2/ In principle, a policy of awardirg appropriate severance pay ir the event of a termination could accomplish the sate eric as a policy of assuring senior employees' jot security. he have seer to gord eviderce that many workers are in fact covered by severarce pay plars mici serve this purpose. As of 1978, only 37 percert of the wajor cortract workforce was covered by severance pay provisiors. Tabulaticrs based cr. the 1974 Employer Expenditures for Employet Corpersatior survey (described in U.S. Bureau of Labor Statistics 19976 j) irdicate ti.at 2 i percent of union production employees and only 3 percent of rorucior. production employees worked in establisiments witere trie erployer Iade contributions to a severance pay or supplemertal luetploynert terefit fund during 1972. Even where severance pay plans exist, it is not $\equiv t$ all clear that the formulas used for determining the level of sertefits appropriately compensate laid off employees for the strear of deferred wages they lose. In addition, at least in the union sector, it appears that severance pay provisions most ofter accompary ratior tian reflace provisions which protect senior employees against being laid off. See Medoff and Abraham [1981] for a discussion of wity one rould rot expect severance pay plans to be the preferred mechanism for protecting secior employees' deferred earnings. 
3/ There were a very small number of responses pertaining to unionized salaried employees which were excluded from the sample we used for analysis.

4/ These data are reported in U.S. Bureau of Labor Statistics [1972].

5/ The probability changes for the union group do not equal those for the nonunion group because the ordered probit is a nonlinear model; that is, the changes in the probabilities of being in the various categories produced by a given change in $\tilde{X} \tilde{\beta}$ depend upon the initial level of $\tilde{X}$.

6/ When we allowed rho to vary freely, it approached one rapidly but the likelihood function failed to converge. We then looked at a series of constrained models, with rho set equal to $0.0,0.2,0.4,0.6,0.8$ and 1.0 in turn. The model with rho equal to one produced the best fit. However, it is unclear what this means.

7/ A number of recent state court decisions have begun to modify the "employment at will" doctrine using the theory of employees having "implied contracts" with their employers, but these jurisdictions are still very much in the minority. See Bureau of National Affairs [1982] for an up-to-date discussion of legal developments in this area.

8/ See Freeman and Medoff [forthcoming]. Giving greater weight to senior workers' preferences may or may not be socially desirable; this point is developed in an interesting paper by Kuhn [1982].

9/ See Freeman and Medoff [forthcoming].

$10 /$ In our survey data, 61 percent of union hourly respondents and 52 percent of nonunion hourly respondents said they had witnessed workforce reductions; the average portion of the relevant work group affected was 14 percent for the union hourlies and 12 percent for the nonunion hourlies. Thus, a reasonable, if crude, estimate is that over the relevant reference period 9 percent of union hourly workers and 6 percent of nonunion hourly workers were permanently laid off. How many of these could conceivably have been senior employees? Only 16 percent 
of our union hourly respondents said that senior employees might sometimes be let go ahead of junior employees; 58 percent of our nonunion hourly respondents said this might sometimes happen. Thus, among union employees layoffs involving roughly 1 percent of the workforce might have affected senior workers, whereas among nonunion employees layoffs involving roughly 3 percent of the workforce might have affected senior workers.

11/ See Blau and Kahn [1981].

12/ See Medoff [1979] for an examination of the impact of collective bargaining on temporary layoffs which analyzes data from the 1974-75 downturn. For discussions of collective bargaining during the current recession, see Dunlop [1982] and Mitchell [1982]. 
Becker, Gary S. and George J. Stigler, "Law Enforcement, Malfeasance and Compensation of Enforcers," Journal of Legal Studies, 3, No. 1 (1974), $1-18$.

Blau, Francine and Lawrence M. Kahn, "The Exit-Voice Tradeoff in the Labor Market: Some Additional Evidence," mimeographed, January 1981.

Bureau of National Affairs, The Employment-At-Will Issue, Washington: The Bureau of National Affairs, Inc., 1982.

Dunlop, John T., "Wage Moderation in 1982 -- Temporary or Lasting?" mimeographed, May 1982.

Freeman, Richard B. and James L. Medoff, What Do Unions Do?, New York: Basic Books, forthcoming.

Harris, Milton and Bengt Holmstrom, "Ability, Performance and Wage Dynamics," mimeographed, April 1981.

Institute for Social Research, A Panel Study of Income Dynamics: Study Design, Procedures, Avallable Data, Ann Arbor, Michigan: The University of Michigan, 1972 .

Institute for Social Research, The 1977 Quality of Employment Survey: Descriptive Statistics, with Comparison Data from the 1969-70 and the 1972-73 Surveys, Ann Arbor, Michigan: The University of Michigan, 1979.

Ioannides, Yannis M. and Christopher A. Pissarides, "Wages and Employment with Firm-Specific Seniority," mimeographed, 1982.

Kuhn, Peter, "Compensation Deferral and Employer Malfeasance in Union and Nonunion Firms," mimeographed, March 1982.

Lazear, Edward P., "Why Is There Mandatory Retirement?" Journal of Political Economy, LXXXVII, No. 6 (December 1979), 1261-84.

Medoff, James L., "Layoffs and Alternatives Under Trade Unionism in U.S. Manufacturing," American Economic Review, LXIX, No. 3 (June 1979), 380-95.

Medoff, James L., and Katharine G. Abraham, "Involuntary Terminations Under Explicit and Implicit Employment Contracts," mimeographed, January 1981.

Mitche11, Daniel J.B., "Recent Union Contract Concessions," mimeographed, April 1982 .

Salop, Joanne and Steven Salop, "Self-Selection and Turnover in the Labor Market," Quarterly Journal of Economics, XC, No. 4 (November 1976), 619-27.

U.S. Bureau of Labor Statistics, Major Collective Bargaining Agreements: Layoff, Recall and Worksharing Procedures, Bulletin No. 1425-13, Washington: Government Printing Office, 1972 . 
U.S. Bureau of Labor Statistics, BLS Handbook of Methods, Bulletin No. 1910, Washington: Government Printing Office, 1976.

U.S. Bureau of Labor Statistics, Characteristics of Major Collective Bargaining Agreements, Bulletin No. 2065, Washington: Government Printing office, 1980 .

Viscusi, W. Kip, "Self-Selection, Learning-Induced Quits, and the Optimal Wage Structure," mimeographed, 1978. 